\title{
Analysis of corneal biometry in a black South African population
}

\begin{tabular}{|c|c|}
\hline $\begin{array}{l}\text { Authors: } \\
\text { Thariq Bagus }{ }^{1} \\
\text { Kerry Alberto }{ }^{2} \\
\text { Michel Muteb } \\
\text { Aubrey Makgc }\end{array}$ & $\begin{array}{l}\text { (D) } \\
\mathrm{a}^{3} \text { (D) } \\
\operatorname{tloe}^{1} \text { (D) }\end{array}$ \\
\hline $\begin{array}{l}\text { Affiliations: } \\
{ }^{1} \text { Division of Op } \\
\text { University of } t \\
\text { Witwatersran } \\
\text { Johannesburg }\end{array}$ & $\begin{array}{l}\text { hthalmology, } \\
\text { he } \\
\text {, South Africa }\end{array}$ \\
\hline $\begin{array}{l}{ }^{2} \text { Helen Joseph } \\
\text { Ophthalmolog } \\
\text { Johannesburg }\end{array}$ & $\begin{array}{l}\text { Hospital } \\
\text { y Department, } \\
\text { South Africa }\end{array}$ \\
\hline $\begin{array}{l}{ }^{3} \text { Division of Ep } \\
\text { and Biostatisti } \\
\text { of the Witwat } \\
\text { Johannesburg }\end{array}$ & $\begin{array}{l}\text { idemiology } \\
\text { cs, University } \\
\text { ersrand, } \\
\text { South Africa }\end{array}$ \\
\hline $\begin{array}{l}\text { Correspondin } \\
\text { Thariq Bagus, } \\
\text { thariq.bagus@ }\end{array}$ & $\begin{array}{l}\text { guthor: } \\
\text { gmail.com }\end{array}$ \\
\hline $\begin{array}{l}\text { Dates: } \\
\text { Received: } 27 \\
\text { Accepted: } 11 \\
\text { Published: } 10\end{array}$ & $\begin{array}{l}\text { ec. } 2018 \\
\text { Apr. } 2019 \\
\text { Sept. } 2019\end{array}$ \\
\hline $\begin{array}{l}\text { How to cite th } \\
\text { Bagus T, Albert } \\
\text { Makgotloe A. } \\
\text { corneal biome } \\
\text { South African } \\
\text { Afr Vision Eye } \\
2019 ; 78(1) \text {, a4 } \\
\text { https://doi.or } \\
\text { aveh.v78i1.49 }\end{array}$ & $\begin{array}{l}\text { is article: } \\
\text { o K, Muteba M, } \\
\text { Analysis of } \\
\text { try in a black } \\
\text { population. } \\
\text { Health. } \\
95 \text {. } \\
5 / 10.4102 / \\
5\end{array}$ \\
\hline $\begin{array}{l}\text { Copyright: } \\
\text { (C) 2019. The A } \\
\text { Licensee: AOS } \\
\text { is licensed unc } \\
\text { Creative Comr } \\
\text { Attribution Lic }\end{array}$ & $\begin{array}{l}\text { uthor(s). } \\
\text { S. This work } \\
\text { ler the } \\
\text { nons } \\
\text { ense. }\end{array}$ \\
\hline Read online: & \\
\hline 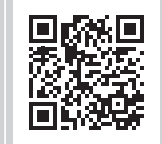 & $\begin{array}{l}\text { Scan this QR } \\
\text { code with your } \\
\text { smart phone or } \\
\text { mobile device } \\
\text { to read online. }\end{array}$ \\
\hline
\end{tabular}

Background: Corneal astigmatism and central corneal thickness are important clinical parameters for cataract surgery and glaucoma, respectively. There is very little research on the central corneal thickness and the prevalence and pattern of corneal astigmatism in black South Africans.

Aim: The aim of this study was to analyse the corneal astigmatism and central corneal thickness of a large population of black South Africans awaiting cataract surgery.

Setting: The study was conducted at St John Eye Hospital, Soweto, South Africa.

Methods: This was a cross-sectional study of a database of adult black patients awaiting cataract surgery. Biometric data was captured using Sheimpflug Imaging (Nidek AL-Scan). Steep corneas (K readings of more than $48 \mathrm{D}$ ) or abnormally thin or thick corneas (central corneal thickness $[C C T]<350 \mu \mathrm{m}$ or CCT $>650 \mu \mathrm{m}$ ) were excluded from the study.

Results: A total of 3231 eyes of 1713 patients were included in this study. Patient ages ranged from 18 to 99 years with a median age of 67 years (interquartile range [IQR] 57-75 years). There were more females $(n=1064)$ than males $(n=649)$. The median central corneal thickness was $494 \mu \mathrm{m}$ (IQR $473 \mu \mathrm{m}-516 \mu \mathrm{m}$ ). The median corneal astigmatism was 0.92 dioptres (IQR 0.551.43 dioptres). A large proportion (45\%) of our study sample patients had 1 dioptre or more of corneal astigmatism.

Conclusion: This analysis of corneal biometric data revealed that a large proportion of black South African patients awaiting cataract surgery have thin corneas and visually significant corneal astigmatism.

Keywords: cornea; central corneal thickness; astigmatism; refractive surgery; cataract surgery; glaucoma.

\section{Introduction}

Modern cataract surgery is increasingly considered to be a refractive surgery with an aim of achieving emmetropia. A study by Behndig et al. ${ }^{1}$ showed that this was only achieved in $55.0 \%$ of cases. A common cause of residual refractive error after cataract surgery is pre-existing corneal astigmatism. $^{2}$ The prevalence of preoperative corneal astigmatism in cataract patients ranges from $22.2 \%$ to $43.9 \%$, and this is mostly reported in European, Middle Eastern and Asian studies. ${ }^{3,4,5,6}$ Visually significant corneal astigmatism is thus a common problem among cataract surgery candidates, but very little is reported on the prevalence and pattern of corneal astigmatism in our African cataract patients.

Central corneal thickness (CCT) is an important clinical parameter that has been widely researched. It has many diagnostic and therapeutic applications in the monitoring of corneal disease, in refractive surgery and, most importantly, in the diagnosis and management of glaucoma. About $19.4 \%$ of the total global population afflicted by primary open-angle glaucoma (POAG) reside within sub-Saharan Africa, and POAG has been shown to occur earlier and progress faster in persons of African descent. ${ }^{7,8}$

A thin CCT has been identified as an independent risk factor for the development of glaucoma, and many studies have shown that people of African descent have thinner corneas than people of European descent. ${ }^{7}$ A study by Sardiwalla et al. ${ }^{9}$ which looked at the CCT of about 200 South Africans demonstrated that black South Africans had a lower mean CCT compared to Indian South Africans $(512.4 \mu \mathrm{m}$ vs. $526.5 \mu \mathrm{m})$. These findings were consistent with what has been reported before in multicentre studies such as the Ocular Hypertension Treatment Study (OHTS). 
The OHTS showed that the mean CCT in African American subjects was $555.7 \mu \mathrm{m} \pm 40 \mu \mathrm{m}$, which was significantly thinner compared to the mean CCT of $579.0 \mu \mathrm{m} \pm 37 \mu \mathrm{m}$ in white subjects. ${ }^{7}$ The South African study, although important, had a very small sample to analyse.

The aim of this study was to analyse the corneal astigmatism and CCT in a large population of black South Africans awaiting cataract surgery.

\section{Methodology}

This was a retrospective analysis of an existing database of biometric data recorded at St John Eye Hospital in Soweto, South Africa. St John Eye Hospital is an ophthalmology department of the Chris Hani Baragwanath Academic Hospital (CHBAH). It has 111 beds and treats about 50000 ophthalmology patients per year. The Chris Hani Baragwanath Academic Hospital is the third largest hospital in the world, occupying around 170 acres $\left(0.70 \mathrm{~km}^{2}\right)$, with approximately 3400 beds and about 6700 staff members. ${ }^{10}$

The biometric measurements were obtained from patients awaiting cataract surgery using Sheimpflug Imaging (Nidek AL-Scan). Ethics approval was obtained from the University of the Witwatersrand Human Research Ethics Committee. The study was conducted in accordance with the tenets of the Declaration of Helsinki.

Biometric data of adult black patients recorded between July 2015 and August 2017 were analysed. Records with incomplete data or erroneous patient details, patients below the age of 18 years and patients with steep corneas (keratometry $[\mathrm{K}]$ readings of more than $48 \mathrm{D}$ [dioptre]) or abnormally thin or thick corneas (CCT $<350 \mu \mathrm{m}$ or CCT $>$ $650 \mu \mathrm{m}$ ) were excluded from the study.

The following variables were extracted from each record: age, gender, race, CCT (micrometres), K1 and K2 (dioptres), axis of astigmatism (degrees). All records were cross analysed with the Chris Hani Baragwanath Academic Hospital records system (Medi-com) to verify each patients' race, gender and date of birth.

Statistical analysis was performed using Statistical Package for Social Sciences (SPSS) software (IBM Corp. Released 2017. IBM SPSS Statistics for Windows, Version 25.0. Armonk, NY: IBM Corp).

\section{Ethical considerations}

Ethical clearance was from the Human Research Ethics Committee, University of the Witwatersrand (reference number: R14/49; protocol number: M171047).

\section{Results}

\section{Patient characteristics}

A total of 2190 patient records were collected. Cross-analysis with the Medi-com records system revealed that 259 records had erroneous patient identifiers, and these were excluded from the study. A further 56 were excluded because of the age being less than 18 years, 66 because of non-black race, 90 because of an abnormally steep cornea and 6 because of an abnormally thick or thin cornea.

A total of 3231 eyes of 1713 patients were included in the study. Patient ages ranged from 18 to 99 years. The median age was 67 years (IQR 57-75) with $56.8 \%$ being older than 65 years of age. There was a higher representation of females $(n=1064)$ compared to males $(n=649)$.

\section{Central corneal thickness}

The distribution of CCT was skewed $(p<0.001)$. The median CCT in this black South African population was $494 \mu \mathrm{m}$ (IQR $473 \mu \mathrm{m}-516 \mu \mathrm{m}$ ) (see Figure 1). Males were found to have thicker corneas than females $(496 \mu \mathrm{m}$ [IQR $475-519 \mu \mathrm{m}$ ] vs. $492 \mu \mathrm{m}$ [IQR $471 \mu \mathrm{m}-514 \mu \mathrm{m}], p<0.01)$. Even though this difference was statistically significant it is unlikely to be clinically significant.

A weakly negative but statistically significant relationship was found between CCT and age $(r=-0.082 ; p<0.01)$.

\section{Corneal astigmatism}

The distribution of corneal astigmatism was skewed $(p<0.001)$. The median corneal astigmatism in this black South African population was found to be $0.92 \mathrm{D}$ (IQR $0.55-1.43 \mathrm{D}$ ). Forty-five percent of patients had $1 \mathrm{D}$ or more of corneal astigmatism, and $12 \%$ had more than $2 \mathrm{D}$ of corneal astigmatism. The median astigmatism in males was $0.93 \mathrm{D}$ (IQR $0.55-1.46 \mathrm{D}$ ), and in females, it was $0.92 \mathrm{D}$ (IQR $0.56-$ $1.4 \mathrm{D})$. This difference was not statistically significant $(p=0.91)$.

There was no statistically significant correlation between corneal astigmatism and age $(r=0.02, p=0.30)$ or corneal astigmatism and CCT $(r=-0.03, p=0.96)$.

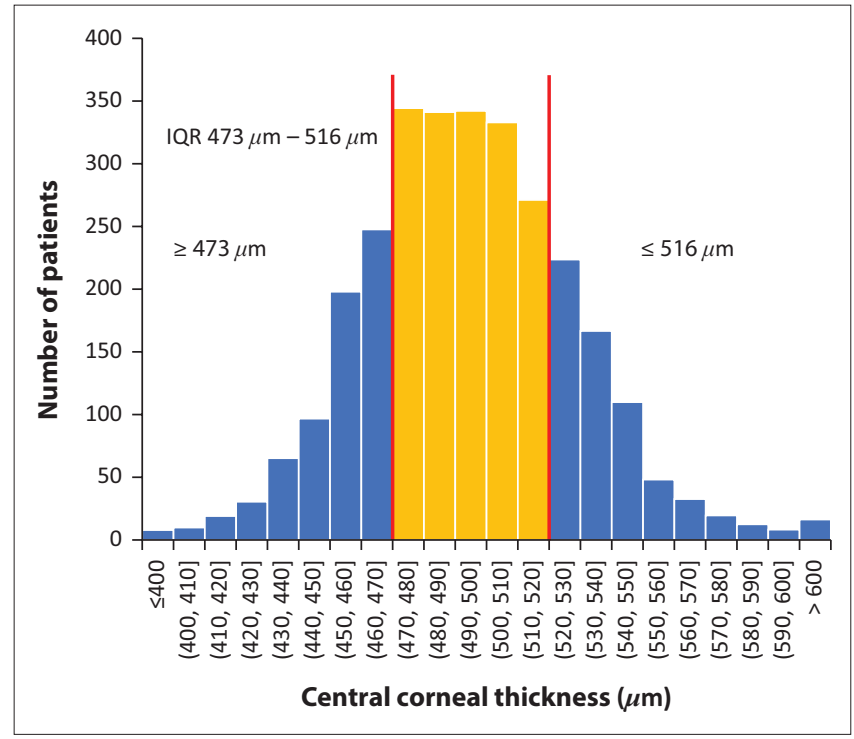

$I Q R$, interquartile range.

FIGURE 1: Distribution of central corneal thickness in a black South African population. 
Overall, $40.2 \%$ of subjects had against-the-rule (ATR) astigmatism, 38.6\% had with-the-rule (WTR) astigmatism and $21.1 \%$ had oblique astigmatism. Irregular astigmatism could not be measured and thus has not been included in this study. There was no statistically significant difference in the axis of corneal astigmatism between males and females $(p=0.48)$.

Figure 2 illustrates the change in the axis of corneal astigmatism with age in a black South African population. We can see that WTR astigmatism is more common in the younger age groups, and ATR astigmatism is more common in the older age groups. A trend line of the two data sets suggests that the conversion from WTR to ATR astigmatism occurs at about 65 years of age.

The mean corneal steepness (mean K) in males was $43.03 \pm$ $1.60 \mathrm{D}$, and in females, it was $43.71 \pm 1.49 \mathrm{D}$. This difference was statistically significant $(p<0.001)$ but is unlikely to be clinically significant.

A weak negative relationship was found between corneal steepness and CCT $(r=-0.11, p<0.001)$, and a weak positive relationship was found between corneal steepness and age $(r=0.11, p<0.001)$. The relationship between the magnitude of corneal astigmatism and corneal steepness was not statistically significant $(r=-0.01, p=0.60)$.

\section{Discussion}

Patients undergoing cataract surgery have increasingly higher post-operative refractive expectations, with emmetropia being the aim of most cataract surgeries. This is only achieved in up to $55 \%$ of cases, ${ }^{1}$ largely because of residual post-operative corneal astigmatism.

This study found corneal astigmatism to be a common problem in a black South African population, with $45 \%$ of patients having visually significant astigmatism of $1 \mathrm{D}$ or greater. This result is comparable to similar studies in other populations. ${ }^{3,45,6}$ Hoffmann et al. analysed 23239 biometry data sets in a high-volume eye surgery centre in Germany and found that $36.0 \%$ of patients had corneal astigmatism of 1.0 D or more. ${ }^{3}$ Ying Cui et al. analysed 6750 eyes of 4561 cataract surgery candidates at the Guangdong Eye Institute in China and found that $43.9 \%$ of eyes had corneal astigmatism of $1.0 \mathrm{D}$ or greater. ${ }^{4}$ Ferrer-Blasco et al. conducted a similar study in Spain and found that among 4540 eyes of 2415 cataract surgery candidates, $22.2 \%$ had corneal astigmatism of $1.5 \mathrm{D}$ or higher. ${ }^{5}$ Mohammadi et al. found a similar result in an Iranian population with $26.2 \%$ of eyes having $1.5 \mathrm{D}$ or more of corneal astigmatism. ${ }^{6}$

There are several methods of correcting corneal astigmatism at the time of cataract surgery, such as corneal relaxing incisions and toric intraocular lenses. Cataract surgeons in

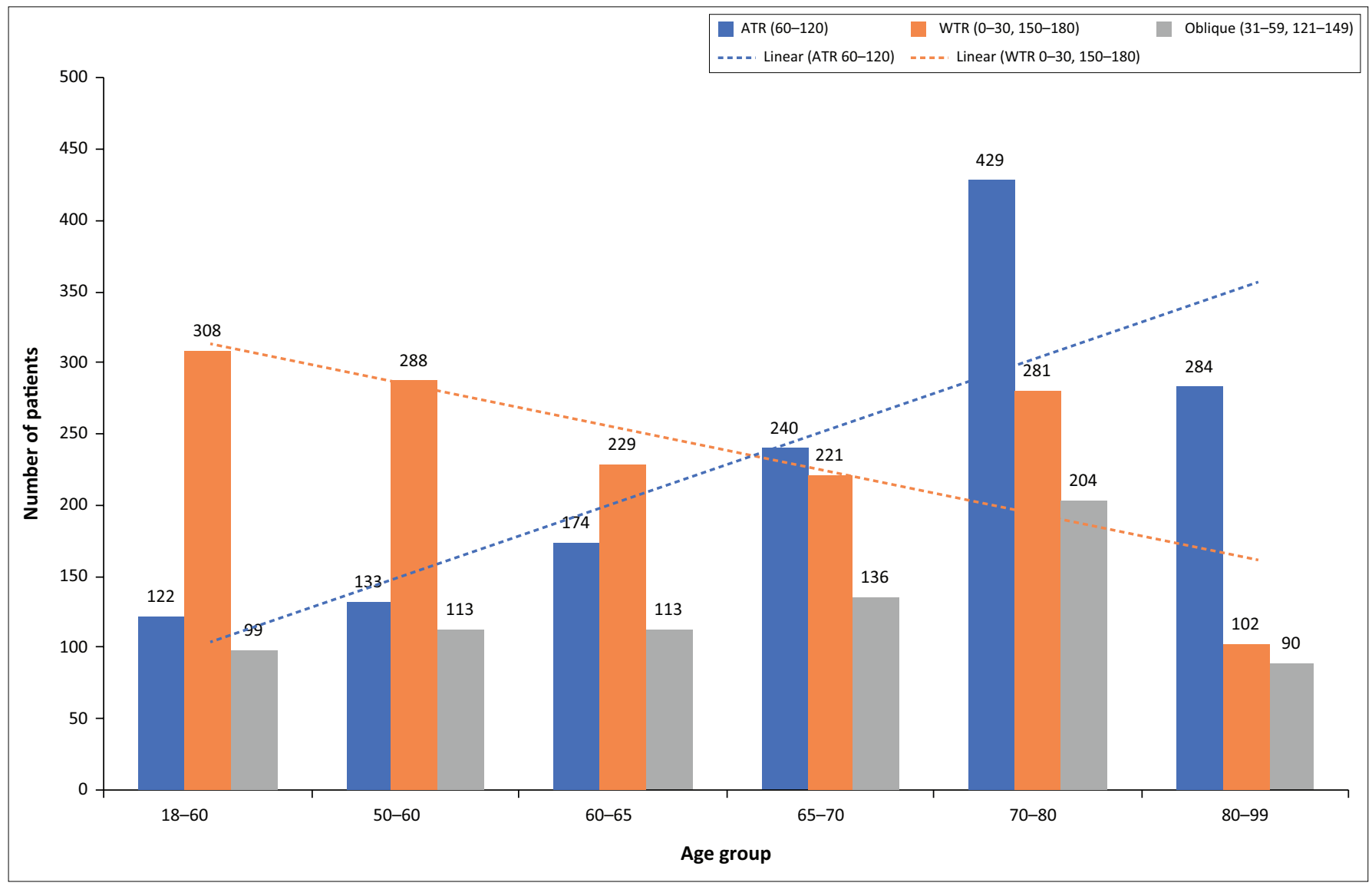

ATR, against-the-rule; WTR, with-the-rule.

FIGURE 2: Distribution of the axis of corneal astigmatism as a function of age in a black South African population. 
our population should therefore anticipate this degree of astigmatism in most of our patients and plan for it accordingly.

Although there was no relationship between the magnitude of corneal astigmatism and age, the axis of corneal astigmatism had a significant correlation with age. Younger patients had predominantly WTR astigmatism and older patients had predominantly ATR astigmatism. Similar findings have been reported before, but the cause remains unclear. ${ }^{11}$ Marin Amat suggested that the shift to ATR astigmatism with age may be because of a combination of a reduction in upper lid pressure because of dermatochalasis and a reduction in the action of the medial rectus muscle. ${ }^{12}$

A weakly negative but statistically significant relationship was found between corneal steepness and CCT $(r=-0.11$; $p<0.001)$. A weakly positive but statistically significant relationship was found between corneal steepness and age $(r=0.11 ; p<0.001)$. This is consistent with the findings of Hayashi et al. ${ }^{11}$ Male participants were found to have steeper corneas than female participants (mean K $43.03 \pm 1.60 \mathrm{D}$ vs. $43.71 \pm 1.49 \mathrm{D} ; p<0.001$ ) but this is unlikely to be clinically significant.

This large cross-sectional study found that black South African participants have a thin CCT (median $494 \mu \mathrm{m}$ IQR $473 \mu \mathrm{m}-516 \mu \mathrm{m}$ ). This result emphasises the importance of CCT as a clinical parameter in the diagnosis and management of glaucoma in black populations. Male participants were found to have thicker corneas than female participants $(496 \mu \mathrm{m}$ [IQR $475 \mu \mathrm{m}-519 \mu \mathrm{m}]$ vs. $492 \mu \mathrm{m}$ [IQR $471 \mu \mathrm{m}-514 \mu \mathrm{m}$ ]; $p<0.01$ ) but this difference is unlikely to be clinically significant. A weakly negative but statistically significant relationship was found between CCT and age $(r=-0.08 ; p<0.01)$. This weak relationship is unlikely to be clinically significant.

Other studies on black South African populations have demonstrated a similarly thin CCT.9,13,14 Studies on other African populations have found CCTs that are comparably thicker than South African corneas. ${ }^{15,16,17,18,19,20,21}$ Incidentally, the CCT tends to be higher in Northern hemisphere countries and lower in Southern hemisphere countries (Figure 3).

To the best of our knowledge, the relationship between CCT and latitude has never been reported on before. This correlative relationship between CCT and latitude needs to be studied further in well-designed prospective studies.

\section{Conclusion}

Visually significant corneal astigmatism is a common problem in a black South African population. To ensure an optimal visual outcome, this astigmatism needs to be corrected at the time of cataract surgery. Black South Africans have a thin CCT, which is comparably thinner than other African populations. There may be a positive correlation between CCT and latitude in black populations around the globe, but further studies are required to assess this relationship.

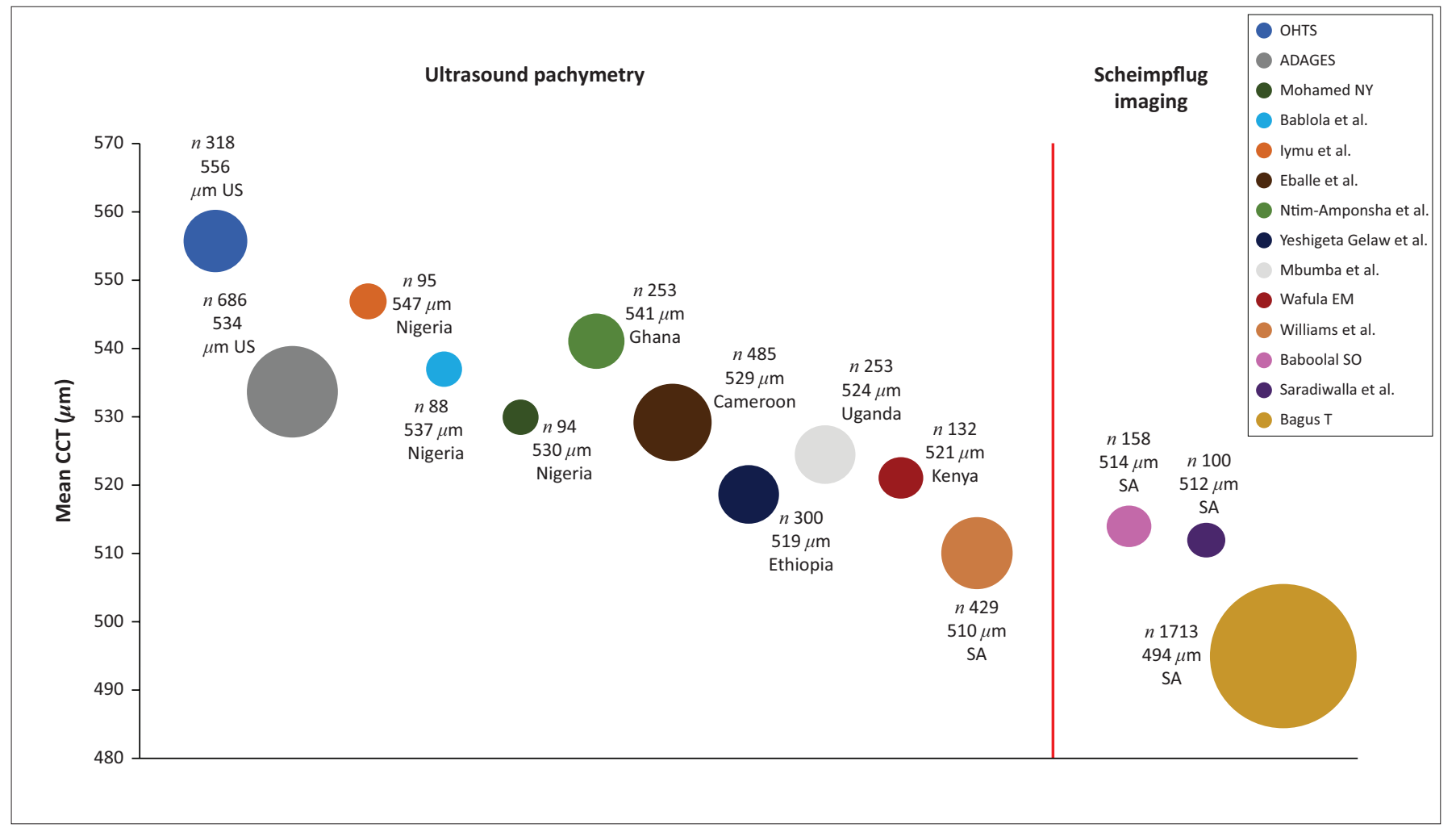

US, United States; SA, South Africa; CCT, central corneal thickness, OHTS, Ocular Hypertension Treatment Study; ADAGES, African descent and glaucoma evaluation study; $n$, number of black participants.

FIGURE 3: Comparison of studies of central corneal thickness in black populations. 
What was known:

- Visually significant corneal astigmatism is a common problem among cataract surgery candidates of European, Middle Eastern and Asian populations.

- Black patients have a thin CCT.

What this article adds:

- Black South African cataract surgery candidates have a prevalence of visually significant corneal astigmatism which is comparable to that found in other populations.

- The CCT of black South Africans was found to be thinner than that found in other African populations.

- There may be a relationship between CCT and latitude. Well-designed prospective studies are required to further evaluate this possible relationship.

\section{Acknowledgements Competing interests}

The authors declare that they have no financial or personal relationships that may have inappropriately influenced them in writing this article.

\section{Authors' contributions}

T.B. was responsible for conceptualisation, study design, data collection, data analysis, statistical analysis and final approval of the manuscript. K.A. was responsible for the supervision, conceptualisation and study design and for the final approval of the manuscript. M.M. was responsible for the statistical analysis and for the critical revision of the manuscript. A.M. was responsible for the data analysis, and for the critical revision and final approval of the manuscript.

\section{Funding information}

This research received no specific grant from any funding agency in the public, commercial or not-for-profit sectors.

\section{Data availability statement}

Request for data should be addressed to T.B. (thariq.bagus@ gmail.com)

\section{Disclaimer}

The views and opinions expressed in this article are those of the authors and do not necessarily reflect the official policy or position of any affiliated agency of the authors.

\section{Reference}

1. Behndig A, Montan P, Stenevi U, et al. One million cataract surgeries: Swedish National Cataract Register 1992-2009. J Cataract Refract Surg. 2011;37(8): 1539-1545. https://doi.org/10.1016/j.jcrs.2011.05.021

2. Alio JL, Abdelghany AA, Fernandez-Buenaga R. Management of residual refractive error after cataract surgery. Curr Opin Ophthalmol. 2014;25(4):291-297. https:// doi.org/10.1097/ICU.0000000000000067

3. Hoffmann P, Hutz W. Analysis of biometry and prevalence data for corneal astigmatism in 23239 eyes. J Cataract Refract Surg 2010;36(9):1479-1485. https://doi.org/10.1016/j.jcrs.2010.02.025

4. Cui Y, Meng Q, Guo H, et al. Biometry and corneal astigmatism in cataract surgery candidates from Southern China. J Cataract Refract Surg 2014;40(10):1661-1669. https://doi.org/10.1016/j.jcrs.2014.01.039

5. Ferrer-Blasco T, Montes-Mico R, Peixoto-de-Matos C, et al. Prevalence of corneal astigmatism before cataract surgery. J Cataract Refract Surg. 2009;35(1):70-75. https://doi.org/10.1016/j.jcrs.2008.09.027

6. Mohammadi M, Naderan M, Pahlevani R, et al. Prevalence of corneal astigmatism before cataract surgery. Int Ophthalmol. 2016;36(6):807-817. https://doi. org/10.1007/s10792-016-0201-z

7. Brandt J, Beiser J, Kass M. Central corneal thickness in the Ocular Hypertension Treatment Study (OHTS). Ophthalmology 2001;108(10):1779-1788.

8. Sample PA, Girkin CA, Zangwill LM. The African Descent and Glaucoma Evaluation Study (ADAGES). Arch Ophthalmol. 2009;127(9):1136-1145. https://doi. org/10.1001/archophthalmol.2009.187

9. Sardiwalla Z, Moodley D, Ndawonde T. A comparative study of central corneal thickness (CCT) and intraocular pressure (IOP) in University of KwaZulu-Natal students of black and Indian ethnicity. S Afr Optom. 2012;71(4):171-177. https:// doi.org/10.4102/aveh.v71i4.83

10. Bowie S. Top 10 largest hospitals in the world. Healthcareglobal.com [Homepage on the Internet]. 2018 [cited 2019 Mar 3]. Available from: https://www. healthcareglobal.com/top10/top-10-largest-hospitals-world.

11. Hayashi K, Hayashi H, Hayashi F. Topographic analysis of the changes in corneal shape due to aging. Cornea. 1995;14(5):527-532.

12. Marin Amat M. Les Variations Physiologiques de la Courbure de la Cornee Pendant la vie; Leur Importance et transcendence dans la Refraction Oculaire. Bull Soc Belge Ophthalmol. 1956;113(1):251-293.

13. Williams SEI, Carmichael TR, Allingham RR, et al. The genetics of POAG in black South Africans: A candidate gene association study. Sci Rep. 2015;5:8378. https:// doi.org/10.1038/srep08378

14. Baboolal SO, Smit DP. South African Eye Study (SAES): Ethnic differences in central corneal thickness and intraocular pressure. Eye 2018;32(4):749-756. https://doi. org/10.1038/eye.2017.291

15. Babalola $O E$, Kehinde AV, lloegbunam AC, et al. A comparison of the Goldmann applanation and non-contact (Keeler Pulsair EasyEye) tonometers and the effect of central corneal thickness in indigenous African eyes. Ophthalmic Physiol Opt. 2009;29(2):182-188. https://doi.org/10.1111/j.1475-1313.2008. 00621.x

16. Ntim-Amponsah CT, Seidu AY, Essuman VA, et al. A study of central corneal thickness in glaucoma and nonglaucoma patients in a West African population. Cornea. 2012;31(10):1093-1096. https://doi.org/10.1097/ICO. ob013e31823c51f7

17. Eballe AO, Koki G, Ellong A, et al. Central corneal thickness and intraocular pressure in the Cameroonian nonglaucomatous population. Clin Ophthalmol. pressure in the Came
2010;(1):717-724.

18. Iyamua $E$, lyamub JE, Amadasuna $G$. Central corneal thickness and axial length in an adult Nigerian population. J Optom. 2013;6(3):154-160. https://doi. org/10.1016/j.optom.2012.09.004

19. Gelaw Y, Kollmann M, Irungu NM, et al. The influence of central corneal thickness on intraocular pressure measured by Goldmann applanation tonometry among selected Ethiopian communities. J Glaucoma. 2010;19(8):514-518. https://doi. selected Ethiopian communities. J G
org/10.1097/IJG.0b013e3181ca7708

20. Mohamed NY, Hassan MN, Mohamed Ali NA. Central corneal thickness in Sudanese population. Sud J Ophthalmol. 2009;1(1):29-32.

21. Mbumba BF, Kagame K, Onyango J, et al. Characteristics of glaucoma in black African patients attending Ruharo eye centre, South Western Uganda. East Afr J Ophthalmol. 2012;16(1):4. 